\title{
STUDY ON COMPLEX EQUILIBRIA BETWEEN DIVALENT TRANSITION METALS (Co, Ni AND Cu) AND L-METHIONINE IN A MEDIUM OF SLS-WATER MIXTURE
}

\author{
R. Neeraja $a^{1,2}$, G. H. Bindu ${ }^{1, \bigotimes}$, M. Ramanaiah ${ }^{3}$ and Y. V. Kumar ${ }^{1}$ \\ ${ }^{1}$ Department of Engineering Chemistry, AUCE (A), Andhra University, Visakhapatnam-530003, \\ Andhra Pradesh, India. \\ ${ }^{2}$ Department of Chemistry, Govt. Degree College (Men), Srikakulam-532001, \\ Andhra Pradesh, India. \\ ${ }^{3}$ Department of Chemistry, Aditya Institute of Technology and Management, Tekkali-532201, \\ Andhra Pradesh, India. \\ ${ }^{\square}$ Corresponding Author: himabinduauce@gmail.com
}

\begin{abstract}
A pH metric investigation of binary metal complexes formed by bivalent transition metals $(\mathrm{Co}, \mathrm{Ni}$ and $\mathrm{Cu})$ and $\mathrm{L}-$ methionine (Met), an essential amino acid in a medium of SLS-Water (concentration 0.0-2.5\%) under ambient conditions of $0.16 \mathrm{~mol} / \mathrm{dm}^{3}$ electrolytic strength at $303.0 \mathrm{~K}$ has been studied. The binding strength of metal-ligand complexes was analyzed by MINIQUAD75, a computational program. The model species selectivity is following the statistical variables like $\mathrm{R}$-factor, $\chi^{2}$, skewness and standard deviation etc. The notable species identified here are MLH, ML and $\mathrm{ML}_{2}$ for the three metal $(\mathrm{Co}, \mathrm{Ni}$ and $\mathrm{Cu})$ ligand systems. The fluctuations in binding strength with differ in the composition of the SLS-Water (0.0-2.5\%) mixture can be described on forces of electrostatic along with non-electrostatic grounds. Possible species distribution listed out at different $\mathrm{pH}$ was shown as distribution diagrams.
\end{abstract}

Keywords: Chemical Equilibria, L-methionine, SLS, Binding Constants and MINIQUAD75.

RASĀYAN J. Chem., Vol. 14, No.2, 2021

\section{INTRODUCTION}

In the recent past, researchers made an extensive study on the chemical speciation of metal ions with different ligands. ${ }^{1-5}$ In living organisms, the metal ions in biofluids exist either as non-convertible form or freely bind to ligands in metal-containing proteins. These freely bonded metal (like $\mathrm{Co}, \mathrm{Ni}, \mathrm{Cu}$ and $\mathrm{Zn}$ ) ions be in a reversible steady state with metal ions of a similar kind that existed in biofluids. These simultaneous equilibria associated with different metal ions as well as biological ligands which are important in biofluids were reported earlier. ${ }^{6}$

L-methionine (Met), sulfur-containing aliphatic indispensable amino acid occurs mostly in foods and is found in tissues or organs. In proteins biosynthesis acted as a precursor for succinoyl CoA, homocysteine, cysteine, creatine and carnitine. Met impairs the metabolic rate of liver injury, reduction of muscle mass, dermal lesions and Lethargy. ${ }^{7}$ Cobalt is an essential trace metal for the human body to produce red blood cells. Cobalamine (Vitamin $\mathrm{B}_{12}$ ) acted as a coenzyme containing a Corrine ring tightly bound to the metal cobalt in the synthesis of two human enzymes namely methionine synthase and methyl malonyl CoA mutase. ${ }^{7}$ Cobalt plays a major part in the functioning of the nervous system properly. Low intake of cobalt causes hematological disorders like pernicious anemia and neurological disorders.

Owing to our symbiotic existence, nickel is essential for the survival of some of the microbes on which we depend for survival. Human gastric pathogen Helicobacter pylori possess two Ni-based enzymes [NiFe] hydrogenase and urease. ${ }^{7}$ Some H. Pylori infections are treated by targeting the Ni-enzymes to prevent the healing of ulcers. Copper-containing enzymes and proteins are involved in the biological process including respiration, angiogenesis and neuromodulation. Copper proteins undergo cellular actions like redox reactions (electron transfer), $\mathrm{O}_{2}$ carrier, oxygenation, oxidation reactions, reduction reactions and disproportionation. ${ }^{8,9}$ Thus, the study of chemical speciation of the mentioned systems has 
been examined by considering their participation in biological systems. Hence, the authors have studied the effect of SLS on the complex equilibria of Met. This kind of research illustrates the active part played by amino acid residues along with substrate-containing catalytic cavities that exist in enzymes and proteins.

\section{EXPERIMENTAL}

\section{Materials}

Chemicals of analytical reagent grade were used to prepare solutions in triple distilled water. Lmethionine (E-Merk, Germany) $1.0 \times 10^{-1} \mathrm{~mol} / \mathrm{dm}^{3}$, divalent metal nitrates of $\mathrm{Co}, \mathrm{Ni}$ and $\mathrm{Cu}$ of $1.0 \times 10^{-1}$ $\mathrm{mol} / \mathrm{dm}^{3}$ were prepared by utilizing $0.16 \mathrm{~mol} / \mathrm{dm}^{3}$ mineral acid $\left(\mathrm{HNO}_{3}\right)$ to reduce the formation of metal hydroxides and increase the solubility of the Met. Sodium lauryl sulphate (Merck, India) was utilized without any further purification. $2.0 \times 10^{-1} \mathrm{~mol} / \mathrm{dm}^{3} \mathrm{HNO}_{3}$ (Qualigens, India) and $4.0 \times 10^{-1} \mathrm{~mol} / \mathrm{dm}^{3}$ sodium hydrate (Qualigens, India) were prepared. $\mathrm{NaNO}_{3}$ (Nitratine) $\left(2.0 \mathrm{~mol} / \mathrm{dm}^{3}\right)$ (Qualigens, India) was used to keep up a constant ionic medium in the titrator. The concentration of sodium hydroxide and $\mathrm{HNO}_{3}$ were checked by Gran-Plot method ${ }^{10}$. To evaluate the errors in constituents concentration, the information has been applied to the analysis of variance (ANOVA). ${ }^{11}$

\section{Instrumentation}

A well-calibrated Elico pH meter of model LI-120having readability 0.01 connected to an ion-selective electrode was utilized to obtain the titrimetric data which can monitor the $\mathrm{H}^{+}$ions. Immerse the $\mathrm{pH}$ measured sensor in a homogeneous mixture of SLS-water maintaining a uniform ionic strength until the electrode reaches the medium concentration. Every titration was done in an SLS-water medium with a concentration range of 0.0 to $2.5 \%$ by the constant progress of 0.5 , under ambient conditions of electrolyte $\left(\mathrm{NaNO}_{3}\right)$ concentration and temperature are $0.16 \mathrm{~mol} / \mathrm{dm}^{3}$ and $303.0 \pm 0.1 \mathrm{~K}$ respectively. The considerable variations (asymmetrical potential, activity coefficient, error in $\mathrm{Na}^{+}$and dissolved $\mathrm{Co}_{2}$ ) that occur at the glass membrane are accountable for the correction factor. ${ }^{12}$

\section{Analytical Procedures}

To evaluate the stability of the binary species formed in the micelle, several alkali metric titrations were done with strong mineral acid. Now the reference electrode was saturated with SLS-water mixture alike with the composition of the titrant. The titrimetry experiments were conducted with $4.0 \times 10^{-1} \mathrm{~mol} / \mathrm{dm}^{3}$ sodium hydrate solution with various metal, ligand ratios $(1: 2.5,1: 3.5$ and 1:5) to a volume of $50 \mathrm{~mL}$ of the titrant containing $0.1 \mathrm{mmol}$ mineral acid. ${ }^{13}$

\section{Modeling Strategy}

The correction factor was determined from free acid titration data subjected to a computational program of SCPHD. ${ }^{14}$ Binding energies $(\log \beta)$ of the metal complexes obtained in the medium were determined by MINIQUAD75 ${ }^{15}$, a computational program that imposes the efficiency of the Least-Squares method of regression analysis with basic refinement and credible merging of the Marquardt algorithm. Throughout the process of evaluation of binding energies of met complexes, $\log \mathrm{F}$ and acidity constants of Met were made to be constant. The shift in the stabilities of metal complexes with the composition of the medium influenced by interactions between solute particles themselves along with solute and solvent particles interactions tends to create electrostatic and non-electrostatic forces.

\section{RESULTS AND DISCUSSION}

The outcomes acquired from fine apt models were the kind of species accompanied with their binding energies together with statistical measures was shown in Table-1.

\section{Residual Analysis}

Poor divergence values of binding constants recommended the correctness of these statistical measures. The summation of least squares of all analysis points, such as alteration in the composition of constituents (divalent metal ions of $\mathrm{Co}, \mathrm{Ni}$ and $\mathrm{Cu}$, met and $\mathrm{H}^{+}$ions) in every step of the experimental point rectified for degrees of freedom, $\mathrm{U}_{\text {corr }}$ is very low. The average value, standard error (SD) and mean divergence are 
RASĀYAN J. Chem.

Vol. 14 | No. 2 |1126-1132| April - June | 2021

significantly low of a system; express the residuals are approaches average value nearly equal to zero was scattered slightly. Usually, a typical Gaussian distribution system kurtosis will be ' 3 ' comply mesokurtic pattern. ${ }^{16}$ If the value $<3$, the error dispersion graph is flat followed by platykurtic or the value is $>3$, the error dispersion graph is sharp following leptokurtic. The current study of kurtosis data reveals that most of the systems follow leptokurtic and very few follow platykurtic. In the table skewness varied from -0.9 to 1.61 indicate the residuals follow Gaussian distribution. Thus least-squares method applies to the current results. Residual factor(R-factor) has a small value is another statistical evidence factor for the aptness of the model. These statistical measures thus exhibit the fine apt models depict the bivalent metal $(\mathrm{Co}, \mathrm{Ni}$ and $\mathrm{Cu})$ complexes in SLS-water mixtures.

Table-1: Statistical Measures of Fine apt Chemical Models of Co(II), Ni(II) and Cu(II) - Met Complexes in SLSWater mixtures; Temperature $=303 \mathrm{~K}$, Electrolyte Strength $=0.16 \mathrm{~mol} / \mathrm{dm}^{3}$

\begin{tabular}{|c|c|c|c|c|c|c|c|c|c|c|}
\hline \multirow{2}{*}{$\begin{array}{c}\% \mathrm{w} / \mathrm{v} \\
\text { SLS }\end{array}$} & \multicolumn{3}{|c|}{$\log \beta \mathrm{mlh}(\mathrm{SD})$} & \multirow{2}{*}{$\begin{array}{c}\mathrm{pH} \\
\text { range }\end{array}$} & \multirow{2}{*}{ NP } & \multirow{2}{*}{ Ucorr } & \multirow{2}{*}{ Skewness } & \multirow{2}{*}{ Kurtosis } & \multirow{2}{*}{$\chi^{2}$} & \multirow{2}{*}{$\begin{array}{c}\mathrm{R}- \\
\text { factor }\end{array}$} \\
\hline & 110 & 111 & 120 & & & & & & & \\
\hline \multicolumn{11}{|c|}{$\mathrm{Co}(\mathrm{II})$} \\
\hline 0.0 & $3.28(20)$ & $10.53(13)$ & $5.65(37)$ & $1.69-8.7$ & 86 & 7.92 & -0.27 & 3.78 & 53.01 & 0.022 \\
\hline 0.5 & $3.90(19)$ & $11.07(25)$ & $6.50(11)$ & $1.95-8.9$ & 90 & 8.83 & 0.06 & 3.91 & 67.87 & 0.0172 \\
\hline 1.0 & $4.98(11)$ & $11.90(23)$ & $7.48(19)$ & $1.78-9.5$ & 130 & 7.72 & 0.11 & 3.05 & 24.11 & 0.0108 \\
\hline 1.5 & $5.32(19)$ & $12.09(14)$ & $8.60(18)$ & $2.0-8.6$ & 118 & 2.9 & -0.28 & 3.29 & 8.98 & 0.0196 \\
\hline 2.0 & $5.97(14)$ & $13.18(12)$ & $9.26(14)$ & $1.8-9.0$ & 128 & 0.95 & 0.33 & 3.8 & 19.08 & 0.0103 \\
\hline 2.5 & $7.03(11)$ & $14.40(26)$ & $9.90(12)$ & $1.77-8.8$ & 88 & 2.14 & -0.69 & 4.56 & 57.7 & 0.0225 \\
\hline \multicolumn{11}{|c|}{$\mathrm{Ni}(\mathrm{II})$} \\
\hline 0.0 & $5.59(08)$ & $11.56(06)$ & $8.98(12)$ & $1.69-8.7$ & 126 & 0.98 & 0.09 & 5.56 & 64.5 & 0.0097 \\
\hline 0.5 & $5.90(31)$ & $11.71(23)$ & $10.0(34)$ & $1.67-8.2$ & 92 & 7.2 & 0.29 & 3.86 & 77.51 & 0.024 \\
\hline 1.0 & $5.72(10)$ & $11.55(11)$ & $9.08(52)$ & $1.89-8.5$ & 88 & 8.1 & 0.93 & 3.15 & 45.52 & 0.005 \\
\hline 1.5 & $5.99(04)$ & $11.99(03)$ & $10.58(04)$ & $2.0-8.6$ & 35 & 0.9 & 1.61 & 8.11 & 26.43 & 0.005 \\
\hline 2.0 & $5.76(23)$ & $12.75(22)$ & $8.65(31)$ & $1.8-9.0$ & 39 & 10.6 & 0.37 & 3.72 & 26.66 & 0.0096 \\
\hline 2.5 & $4.90(10)$ & $12.53(29)$ & $6.5(13)$ & $1.77-9.5$ & 66 & 3.53 & -0.9 & 5.07 & 12.26 & 0.0101 \\
\hline \multicolumn{11}{|c|}{$\mathrm{Cu}(\mathrm{II})$} \\
\hline 0 & $7.19(13)$ & $11.18(08)$ & $13.56(12)$ & $1.63-5.2$ & 134 & 2.56 & -0.19 & 3.38 & 26.7 & 0.0154 \\
\hline 0.5 & $7.76(16)$ & $11.37(11)$ & $15.0(12)$ & $1.67-5.0$ & 47 & 1.18 & 0.16 & 2.53 & 6.12 & 0.0114 \\
\hline 1.0 & $8.15(31)$ & $12.34(29)$ & $14.78(31)$ & $1.88-5.2$ & 53 & 4.38 & 0.25 & 2.98 & 20.37 & 0.028 \\
\hline 1.5 & $8.98(01)$ & $11.58(08)$ & $15.9(03)$ & $\begin{array}{l}1.95- \\
4.65\end{array}$ & 117 & 3.61 & 0.9 & 4.93 & 12.1 & 0.0063 \\
\hline 2.0 & $9.0(12)$ & $12.76(11)$ & $15.47(30)$ & $1.8-4.9$ & 112 & 2.69 & -0.28 & 3.56 & 15.86 & 0.0118 \\
\hline 2.5 & $9.08(01)$ & 13.34(11) & 16.21(10) & $1.76-5.5$ & 109 & 6.33 & 0.44 & 2.8 & 19.98 & 0.026 \\
\hline
\end{tabular}

\section{Effect of Observational Errors on Fine Apt Model}

To get fine apt models, undergo analytical assessment and operation carried out at different practical conditions, a study was conducted by knowingly impose errors in constituents concentration $\mathrm{NaOH}$, $\mathrm{HNO}_{3}$, Met and metal (Co, Ni and $\left.\mathrm{Cu}\right)$ ions). The obtained outcomes show that the binding constants of bivalent metal complexes affected by $\mathrm{NaOH}$ concentration is more compared to other constituents and follows the trend $\mathrm{NaOH}>\mathrm{HNO}_{3}>$ met $>$ metal ions $(\mathrm{Co}, \mathrm{Ni}$ and $\mathrm{Cu})>$ total volume $>\log \mathrm{F}$. Sometimes the rejection of species may occur or species with high SD happened while introducing inaccurate concentrations. These trails strengthen the selected model's suitability.

Table-2: Effect of Errors in Controlling Statistical Measures of Coordination Complexes of Co(II)-Met Binding Constants in $1.0 \% \mathrm{w} / \mathrm{v}$ SLS-Water Mixture.

\begin{tabular}{c|c|c|c|c}
\hline \multirow{2}{*}{ Constituents } & \multirow{2}{*}{$\%$ of Error } & \multicolumn{3}{|c}{$\log \beta \mathrm{mlh}(\mathrm{SD})$} \\
\cline { 2 - 4 } & & $\mathrm{ML}$ & $\mathrm{MLH}$ & $\mathrm{ML}_{2}$ \\
\hline \multirow{3}{*}{ Alkali } & 0 & $4.98(11)$ & $11.90(23)$ & $7.48(19)$ \\
\cline { 2 - 5 } & -5 & $4.00(65)$ & $11.63(25)$ & $7.98(28)$ \\
\cline { 2 - 5 } & -2 & Rejected & $12.42(46)$ & $9.35(47)$ \\
\hline
\end{tabular}


RASĀYAN J. Chem.

Vol. 14 | No. 2 |1126-1132| April - June | 2021

\begin{tabular}{|c|c|c|c|c|}
\hline & +5 & Rejected & $24.64(53)$ & $23.6(56)$ \\
\hline \multirow{4}{*}{ Acid } & -5 & Rejected & $24.51(41)$ & $23.00(50)$ \\
\hline & -2 & Rejected & $19.75(39)$ & $17.49(41)$ \\
\hline & +2 & Rejected & $12.67(37)$ & $10.74(38)$ \\
\hline & +5 & Rejected & $11.25(24)$ & $8.94(21)$ \\
\hline \multirow{4}{*}{ Ligand(L) } & -5 & Rejected & $12.14(19)$ & $9.63(20)$ \\
\hline & -2 & Rejected & $12.94(28)$ & $10.31(28)$ \\
\hline & +2 & Rejected & $18.49(40)$ & $15.78(34)$ \\
\hline & +5 & Rejected & $23.37(66)$ & $20.62(66)$ \\
\hline \multirow{4}{*}{ Metal } & -5 & Rejected & $17.17(55)$ & $14.60(55)$ \\
\hline & -2 & Rejected & $18.15(42)$ & $15.52(42)$ \\
\hline & +2 & Rejected & $18.51(42)$ & $15.80(43)$ \\
\hline & +5 & Rejected & $13.37(67)$ & $10.60(67)$ \\
\hline \multirow{4}{*}{ volume } & -5 & Rejected & $12.03(19)$ & $9.32(20)$ \\
\hline & -2 & Rejected & $13.45(23)$ & $10.15(23)$ \\
\hline & +2 & Rejected & $14.87(26)$ & $12.23(31)$ \\
\hline & +5 & Rejected & $18.00(41)$ & $15.23(42)$ \\
\hline \multirow{4}{*}{$\log \mathrm{F}$} & -5 & Rejected & $12.17(23)$ & $9.44(24)$ \\
\hline & -2 & Rejected & $12.56(26)$ & $9.81(27)$ \\
\hline & +2 & Rejected & $13.31(65)$ & $10.56(65)$ \\
\hline & +5 & Rejected & $18.67(40)$ & $15.92(41)$ \\
\hline
\end{tabular}

\section{Effect of Solvent}

The trend in binding constants of metal complexes differs with molar fraction of SLS mostly follow linearity due to progressive reduction in the dielectric constant of SLS-water medium. ${ }^{17}$ Figure-1(a) and (c) describes Met system of bivalent $\mathrm{Co}$ and $\mathrm{Cu}$ binding energies that grows linearly because electrostatic forces overcome non-electrostatic forces. And also from Fig.-1(b) shows the met system of bivalent Ni binding energies increase in linearity with some non-linearity contributing from factors like medium polarity, micelle surface charge along with interactions between metal complex and micellar surface nonelectrostatically ${ }^{18}$.
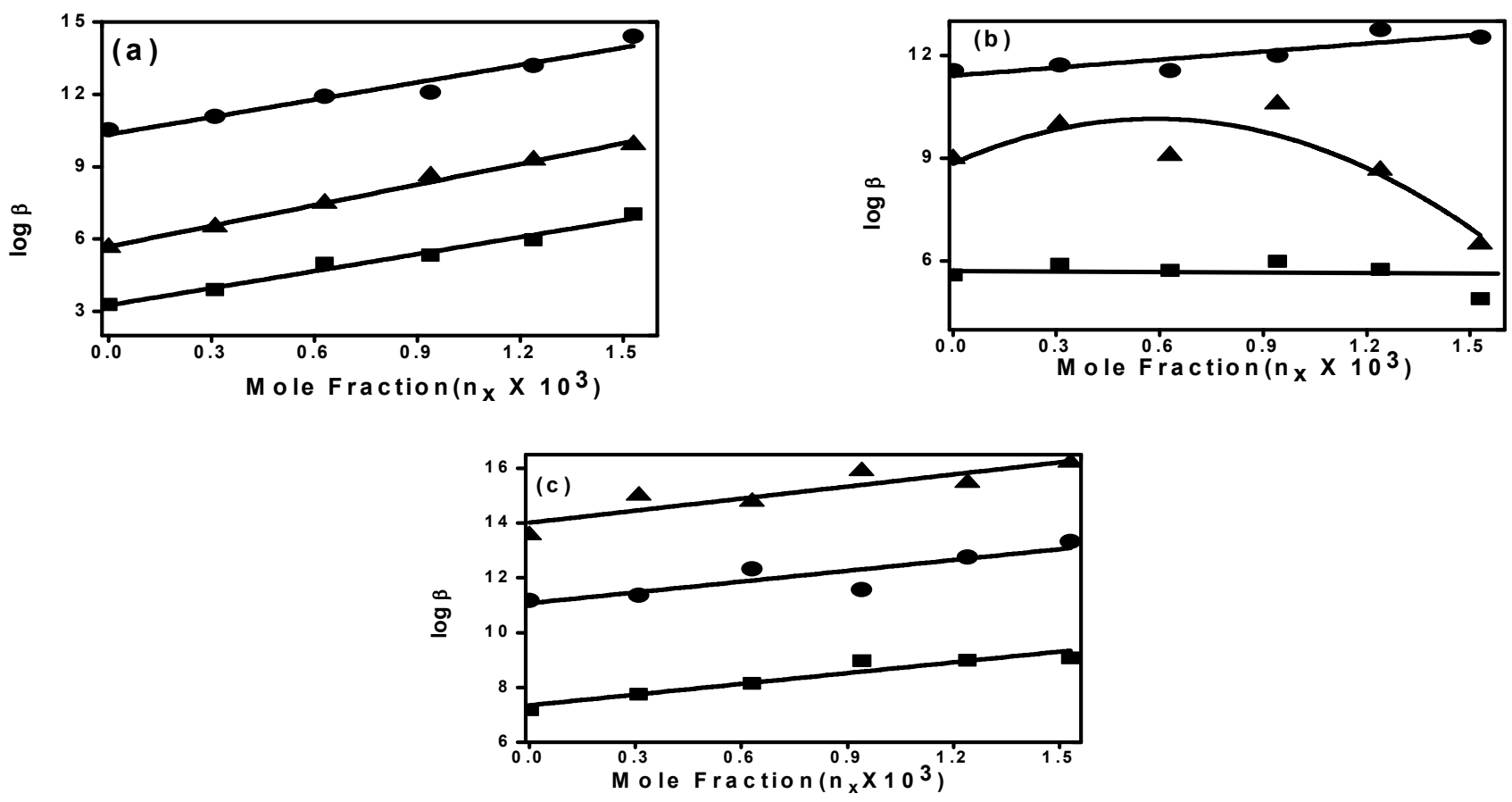

Fig.-1: Change in Stability Constants of Metal - L-Met Complexes in SLS -Water System: (a) Co(II), (b) Ni(II), and (c) $\mathrm{Cu}(\mathrm{II}) ;(\boldsymbol{\square}) \log \beta_{\mathrm{ML}},(\boldsymbol{O}) \log \beta_{\mathrm{MLH}}$ and ( $\left.\boldsymbol{\Delta}\right) \log \beta_{\mathrm{ML} 2}$. 
RASĀYAN J. Chem.

Vol. 14 | No. 2 |1126-1132| April - June | 2021

\section{Distribution Diagrams}

L-methionine, a bidentate ligand possesses an associative amino proton and a dissociative carboxylate proton. Met be presented $2.0<\mathrm{pH}>4.0$ as $\mathrm{LH}_{2}{ }^{+}, 2.0<\mathrm{pH}>10.0$ as $\mathrm{LH}$ and $8.0<\mathrm{pH}>10.0$ as $\mathrm{L}^{-}$in aqueous solution. By considering Met activity with bivalent metal $(\mathrm{Co}, \mathrm{Ni}$, and $\mathrm{Cu})$ ions, the identified and predominant species in this investigation are $\mathrm{MLH}, \mathrm{ML}$ and $\mathrm{ML}_{2}$ for the three metal-met systems in the SLS-water medium. Distribution diagrams of metal-met system in SLS-water medium (from figure 2) acknowledges that the three species identified in the region of $1.69<\mathrm{pH}>9.5$ for $\mathrm{Co}(\mathrm{II}), 1.67<\mathrm{pH}>9.5$ for $\mathrm{Ni}$ (II) and for $\mathrm{Cu}(\mathrm{II}) 1.63<\mathrm{pH}>5.5$ sequentially. The non-bonded pair of electrons in the Nitrogen atom of $-\mathrm{NH}_{2}$ group in L-methionine has a strong potent to combine with $\mathrm{H}^{+}$(protons) in a region of physiological $\mathrm{pH}$. Therefore competitiveness developed between metal $\left(\mathrm{Co}, \mathrm{Ni}\right.$, and $\mathrm{Cu}$ ) ions and $\mathrm{H}^{+}$ions for nitrogen site residing lone pair of electrons, results in metal-ligand complexes with protonated species also. Based on the activity of Met and metal ions and their interactions, the possible proposed structures were presented in Fig.-3.The reduction of unbonded metal ion (FM) concentration signifies the high coordinating ability of L-methionine. The development of possible metal complexes is listed by the steady-state of these equilibria.

\begin{tabular}{|c|c|c|}
\hline $\mathrm{M}(\mathrm{II})+\mathrm{LH}_{2}{ }^{+}$ & $=$ & $\mathrm{MLH}^{2+}+\mathrm{H}^{+}$ \\
\hline $\mathrm{MLH}^{2+}$ & 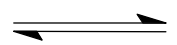 & $\mathrm{ML}^{+}+\mathrm{H}^{+}$ \\
\hline $\mathrm{M}(\mathrm{II})+\mathrm{LH}_{2}^{+}$ & $\rightleftharpoons$ & $\mathrm{ML}^{+}+2 \mathrm{H}^{+}$ \\
\hline $\mathrm{M}(\mathrm{II})+2 \mathrm{LH}_{2}^{+}$ & $\rightleftharpoons$ & $\mathrm{ML}_{2} \mathrm{H}_{2}{ }^{2+}+2 \mathrm{H}^{+}$ \\
\hline $\mathrm{ML}_{2} \mathrm{H}_{2}{ }^{2+}$ & $\rightleftharpoons$ & $\mathrm{ML}_{2}+2 \mathrm{H}^{+}$ \\
\hline $\mathrm{M}(\mathrm{II})+3 \mathrm{LH}_{2}^{+}$ & $\Gamma$ & $\mathrm{ML}_{3} \mathrm{H}_{3}{ }^{2+}+3 \mathrm{H}^{+}$ \\
\hline $\mathrm{M}(\mathrm{II})+2 \mathrm{LH}_{2}^{+}$ & $=$ & $\mathrm{ML}_{2} \mathrm{H}^{+}+3 \mathrm{H}^{+}$ \\
\hline $\mathrm{M}(\mathrm{II})+2 \mathrm{LH}_{2}^{+}$ & $=$ & $\mathrm{ML}_{2}+4 \mathrm{H}^{+}$ \\
\hline $\mathrm{M}(\mathrm{II})+3 \mathrm{LH}_{2}^{+}$ & $\longrightarrow$ & $\mathrm{ML}_{3} \mathrm{H}_{2}^{+}+4 \mathrm{H}^{+}$ \\
\hline $\mathrm{M}(\mathrm{II})+3 \mathrm{LH}_{2}^{+}$ & & $\mathrm{ML}_{3} \mathrm{H}+5 \mathrm{H}^{+}$ \\
\hline $\mathrm{M}(\mathrm{II})+3 \mathrm{LH}_{2}^{+}$ & $=$ & $\mathrm{ML}_{3}^{-}+6 \mathrm{H}^{+}$ \\
\hline
\end{tabular}
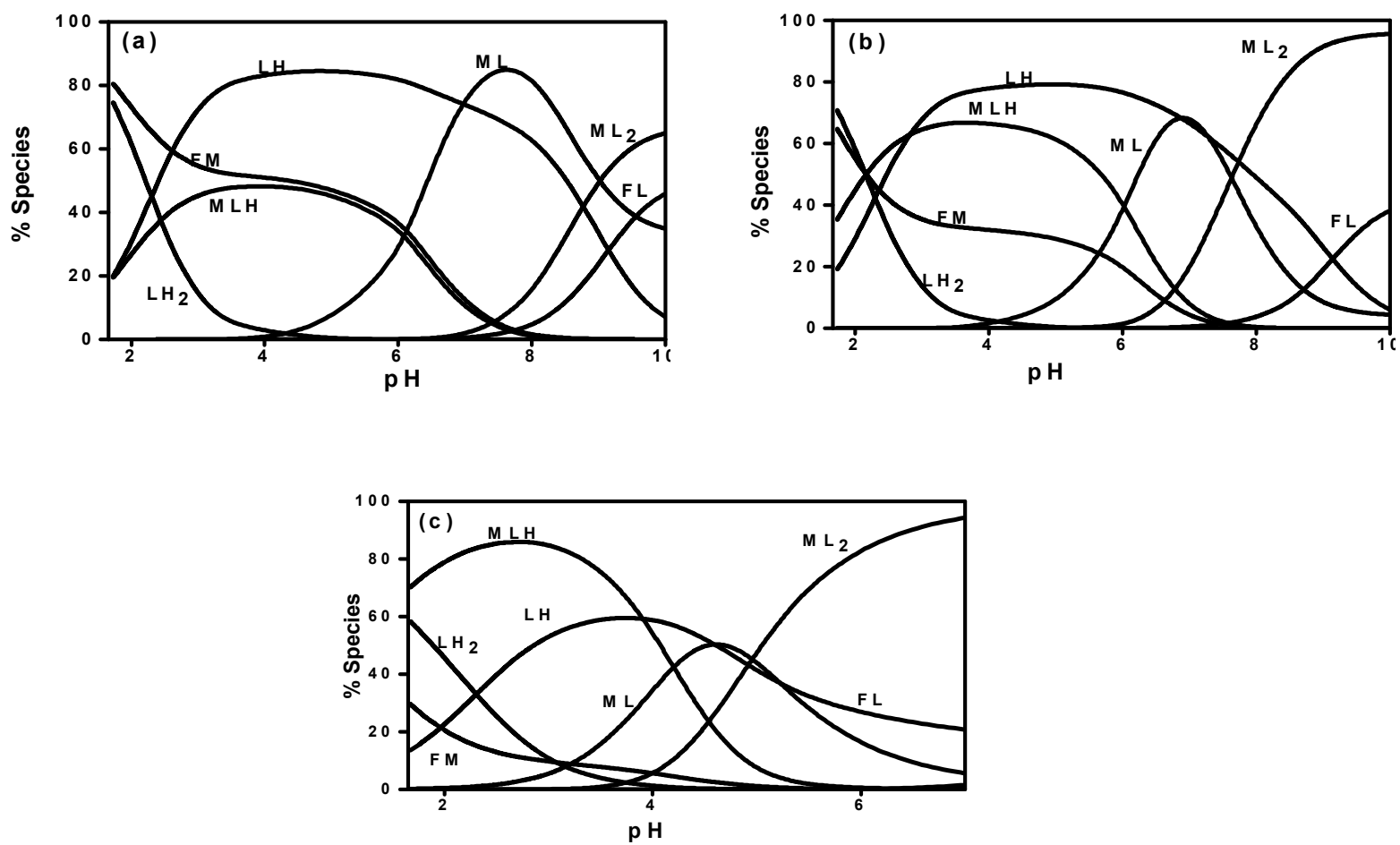

Fig.-2: Distribution Diagrams of Coordination Complexes of L-Met in 1.0\% w/v SLS-Water Medium. (a) Co(II), (b) $\mathrm{Ni}(\mathrm{II})$ and $(\mathrm{c}) \mathrm{Cu}(\mathrm{II})$. 
RASĀYAN J. Chem.

Vol. 14 | No. 2 |1126-1132| April - June | 2021

\section{Proposed Design of Complexes}

The catalytic cavities in the L-methionine actively participate in the generation of metal-met complexes forming strong chelate rings (five-membered). Most of the research studies conveyed that metal complexes of met are found to be a structure of octahedral. In addition to these facts, based on VSEPR (valence shell electron pair repulsion) theory also recommended that Met complexes of bivalent metals $(\mathrm{Co}, \mathrm{Ni}$ and $\mathrm{Cu})$ must be arranged in octahedral form caused by the existence of six electron pairs, therefore suggested the proposed structures in Fig.-3.

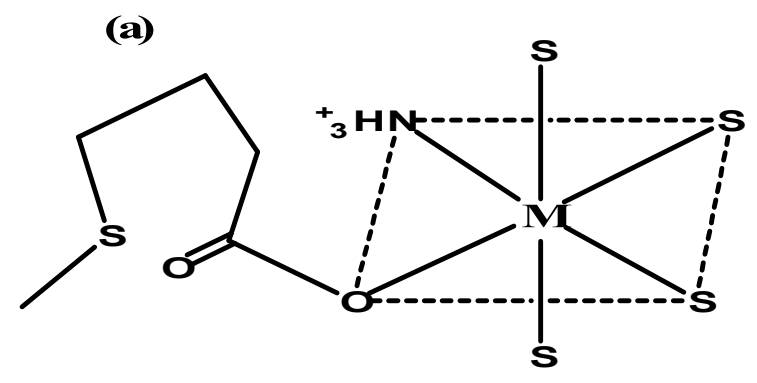

MLH

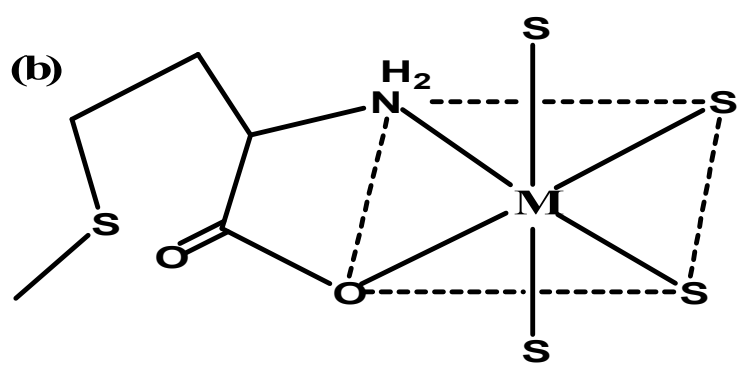

ML

(c)

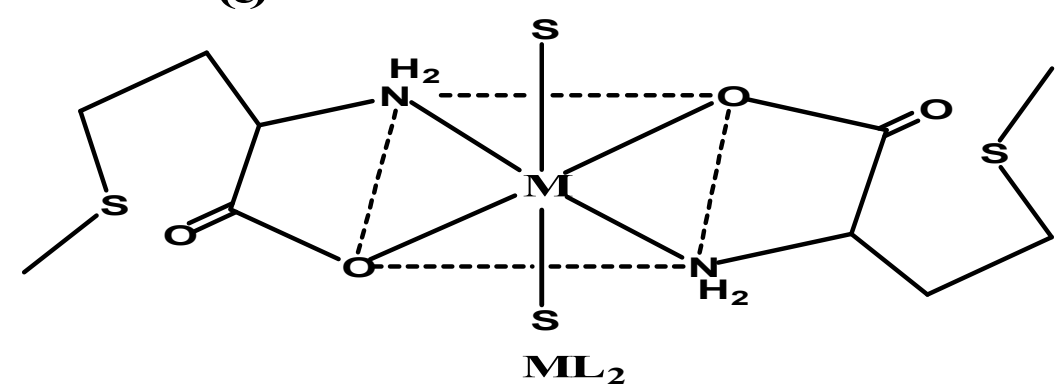

Fig.-3: Structure of Coordination Complexes of L-Met (S refers to Solvent or $\mathrm{H}_{2} \mathrm{O}$ Molecules).

\section{CONCLUSION}

1. The pH metric work of bivalent metal $(\mathrm{Co}, \mathrm{Ni}$ and $\mathrm{Cu})$ complexes of L-methionine in SLS-water medium investigate the generation of $\mathrm{ML}, \mathrm{ML}_{2}$ and $\mathrm{MLH}$ for all the three metal ions.

2. The linear variation or almost linear variation of the metal complexes except in $\mathrm{Ni}$ (II), the binding energies with molar fraction of the medium suggests electrostatic forces are dominative than nonelectrostatic forces. But in $\mathrm{Ni}(\mathrm{II})$ complexes non-electrostatic forces are dominative over electrostatic forces.

3. Binding energies of metal complexes affected by constituents on insertion of errors in their concentration follow the order $\log \mathrm{F}<$ total volume $<$ metal $(\mathrm{Co}, \mathrm{Ni}$ and $\mathrm{Cu})$ ions $<$ Met $<\mathrm{HNO}_{3}<$ $\mathrm{NaOH}$.

4. Speciation study of L-Met with trace metal ions in anionic solvent medium should be pivotal data for biochemists and this information is useful in pharmaceutical applications like drug designing and drug delivery systems etc.

\section{REFERENCES}

1. K. V. Lavanya, V. M. Rao and G. N. Rao, Oxidation Commmunication, 31, 398(2008).

2. M. P. Latha, V. M. Rao, T. S. Rao and G. N. Rao, Bulletin of the Chemical Society of Ethiopia, 21(3), 363(2007), DOI:10.4314/bcse.v21i3.21217

3. A. Kajala and O. D. Gupta, Rasayan Journal of Chemistry, 2(4), 833(2009).

4. A. B. Patil, Rasayan Journal of Chemistry, 5(4), 500(2012).

5. A.B .Patil, Rasayan Journal of Chemistry, 6,161(2013).

6. P. M. May, P. W. Linder, D. R. Williams, Journal of the Chemical Society, Dalton Transactions(6), 588(1977), DOI: 10.1039/DT9770000588 
RASĀYAN J. Chem.

Vol. 14 | No. 2 |1126-1132| April - June | 2021

7. Ch. Prinessa and J. Sadler Peter, Philosophical Transactions of The Royal Society A Mathematical Physical and Engineering Sciences, 373(2037), 20140182 (2015), DOI:10.1098/rsta.2014.0182

8. R. H. Holm, P. Kennepohl, E. I. Solomon, Chemical Reviews, 96, 2239(1996), DOI: $10.1021 / \mathrm{cr} 9500390$

9. W. R. Walker, R. R. Reeves, M. Brosnan and G. D. Coleman, Bioinorganic Chemistry, 7, 271(1977).

10. G. Gran, Analytical Chimica Acta, 206, 111(1988), DOI:10.1016/S0003-2670(00)80835-1

11. G. N. Rao, Ph.D. thesis, Andhra University, Visakhapatnam, India, 1989.

12. V. G. Kumari, M. Ramanaiah and B. B. V. Sailaja, Chemical Speciation and Bioavailability, 27, 121(2015), DOI:10.1080/09542299.2015.1087159

13. G. H. Bindu, G. N. Rao, Chemical Speciation and Bioavailability, 23(2), 88(2011), DOI: 10.3184/095422911X13027129908069

14. C. N. Rao, M. Ramanaiah and B. B. V. Sailaja, Bulletin of the Chemical Society of Ethiopia,30(1), 71 (2016), DOI:10.4314/bcse.v30i1.6

15. P. Gans, A. Sabatini and A. Vacca, Inorganica Chimica Acta, 18, 237(1976), DOI:10.1016/S00201693(00)95610-X

16. M. P. Latha, V. M. Rao, T. S. Rao and G. N. Rao, Acta Chimica Slovenica, 54(1), 160(2007).

17. A. K. Singh, D. Manjula, Journal of Indian Chemical Society, 78, 635(2001).

18. A. Bunton, Catalysis Reviews, 20, 10(1979), DOI:10.1080/03602457908065104

[RJC-6187/2020] 